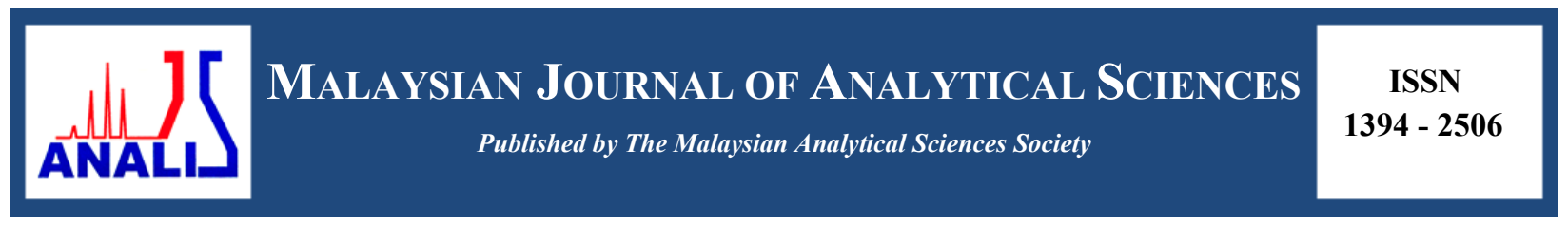

\title{
FORENSIC GAS CHROMATOGRAPHY ANALYSIS OF TIME ELAPSED GASOLINE IN FIRE SCENE INVESTIGATION
}

\section{(Analisis Kromatografi Gas Forensik bagi Gasolin yang Masanya Berlalu dalam Penyiasatan Tempat Kebakaran)}

\author{
Pei Wen Lim, Ahmad Fahmi Lim Abdullah, Kah Haw Chang* \\ Forensic Science Programme, School of Health Sciences, \\ Universiti Sains Malaysia, 16150 Kubang Kerian, Kelantan, Malaysia \\ *Corresponding author: changkh@usm.my
}

Received: 25 September 2017; Accepted: 29 January 2018

\begin{abstract}
Gasoline residues present in fire debris serves as important evidence in arson investigation. In view of safety considerations, fire investigators do not enter fire scene immediately after fire extinguishing activity. In this perspective, gasoline residue in burnt carpet was analysed in relation to time elapsed after a fire to evaluate the influence of evaporative weathering process on the detection of gasoline traces from fire debris. Simulating fire condition, carpet samples poured with gasoline were burned, and the fire was extinguished with water before exposure to varying evaporation time at room temperature. All burnt carpet samples were then extracted by hexane and analysed using gas chromatography-flame ionisation detector. Selected peaks were then subjected to principal component analysis (PCA) for clustering. Experimental results revealed rapid evaporation of gasoline during the first 30 minutes, followed by continuous but non-linear decrease up to one-month interval. Four clusters were found in the PCA plots wherein samples that were subjected to less than nine hours exposure were located close to positive control and could be distinguished from the rest. Hence, it is recommended that safety measures should be completed within nine hours.
\end{abstract}

Keywords: forensic science, fire scene, gasoline detection, gas chromatography, time elapsed

Kehadiran sisa-sisa gasolin pada serpihan kebakaran ialah bukti penting dalam penyiasatan arson. Oleh kerana pertimbangan keselamatan, penyiasat-penyiasat kebakaran tidak memasuki tempat kejadian kebakaran sejurus selepas aktiviti pemadaman api. Dalam perspektif ini, sisa gasolin pada permaidani terbakar telah dianalisis untuk dikaitkan dengan masa berlalu selepas suatu kebakaran, bertujuan untuk menilai kesan proses sejatan terhadap pengesanan gasolin surih daripada serpihan kebakaran. Menerusi simulasi keadaan kebakaran sebenar, sampel permaidani yang dicurahkan dengan gasolin telah dibakar, dan api tersebut dipadamkan dengan air sebelum didedahkan kepada pelbagai tempoh penyejatan pada suhu bilik. Kesemua sampel permaidani terbakar kemudian tertakluk kepada pengekstrakan heksana dan dianalisis menggunakan kromatografi gas-pengesan pengionan nyalaan. Puncak-puncak terpilih kemudiannya tertakluk kepada analisis komponen utama (PCA) untuk tujuan pengelompokan. Keputusan eksperimen telah menunjukkan penyejatan pesat gasolin pada 30 minit pertama, diikuti dengan penurunan secara berterusan tidak linear sehingga tempoh satu bulan. Empat kelompok telah diperolehi dalam plot PCA dan sampel yang didedahkan pada jangka masa kurang daripada sembilan jam terletak berdekatan dengan kawalan positif dan boleh dibezakan daripada yang lain. Justeru, adalah disyorkan bahawa langkah keselamatan perlu diselesaikan dalam jangka masa sembilan jam.

Kata kunci: sains forensik, tempat kejadian kebakaran, pengesanan gasolin, kromatografi gas, masa berlalu 


\section{Lim et al: FORENSIC GAS CHROMATOGRAPHY ANALYSIS OF TIME ELAPSED GASOLINE IN FIRE SCENE INVESTIGATION}

\section{Introduction}

Arson is a willful and malicious burning of property [1]. Statistics from the Fire and Rescue Department Malaysia revealed an annual upward trend of fire breakouts from 2012 to 2016 in which arson was the second major culprit with 5,000 to 10,000 cases annually [2]. Recently, a recent school arson case in Kuala Lumpur that caused 23 deaths shocked the entire nation [3]. This blatant criminal act needs greater investigative effort, particularly in determining the origin and cause of the fire.

Ignitable liquids were frequently used in arson not only to initiate instant burning but also to accelerate burning rate and fire spread. Low cost, widely available and easy to handle hydrocarbon based fuel, such as gasoline was frequently used [4]. Hence, the detection of ignitable liquid residues at the fire scene could serve as an investigative lead to support the hypothesis on the occurrence of arson crime [5-7]. Identifying an arsonist is also closely related with the possibility of collecting and analysing any ignitable liquid in the possession of the suspect [8].

Due to rapid progression and destructive nature of a fire, determination of an arson crime is often difficult. Massive damage from heat commonly leaves only small traces of valuable evidence at a fire scene, particularly the volatile ignitable liquid, such as gasoline [9]. Apart from that, such residues, if recoverable, could have been altered through evaporative weathering accelerated by heat and time elapsed [9]. Theoretically, forensic investigation should start as soon as possible upon fire suppression to recover any remaining residues prior to subsequent loss, but this could be delayed since forensic investigators must ensure that the investigation site is structurally safe or free of lethal toxic gas and heat.

The above situation delineates that there is a time gap between the onset of fire, its suppression and fire scene investigation. It is uncertain on the degree of subsequent loss of volatile ignitable liquid residues upon suppression. In view of this, this study focuses on the analysis of gasoline residues and the influences of time elapsed after a fire on the recovery and detection of gasoline from burnt carpets using gas chromatography technique. This approach could provide additional information to fire investigators even on negative results of ignitable liquid recovered from fire debris; either due to true absence of ignitable liquid used or because of severe evaporative weathering that has rendered the accelerant undetectable. It would also be interesting to estimate the maximum time persistence of gasoline on exposed fire debris at room temperature to allow the fire investigator in planning an appropriate sampling strategy and evidence preservation method prior to laboratory analysis.

\section{Materials and chemicals}

\section{Materials and Methods}

Gasoline (RON 95, Petronas, Kota Bharu) was obtained from a petrol service station near our research laboratory. A common household cotton type carpet purchased from a carpet shop was used as substrate. As this study focused on the comparison of the effect of varying time elapsed towards gasoline profiles, only one type of substrate was used, which was the household carpet that could be found in many residential structures. Distilled water was used to extinguish the simulated fire. Analytical grade hexane used to extract the burnt samples was purchased from Merck (Kenilworth, NJ).

\section{Preparation of carpet samples}

The carpets were cut into square of $5 \mathrm{~cm} \times 5 \mathrm{~cm}$ and placed on the center of a square metal can of $15 \mathrm{~cm} \times 15 \mathrm{~cm}$. Then, $20 \mathrm{~mL}$ of gasoline was spread evenly on the surface of the carpet. Fire was ignited using matches and allowed the gasoline-soaked carpet to burn for 30 seconds followed by extinguishment of fire by spraying $500 \mathrm{~mL}$ distilled water. Unburnt carpet samples with gasoline were used as positive control while a piece of new carpet without gasoline was used as negative control.

In triplicate, the burnt carpets could evaporate at different time interval up to a month at room temperature $(\approx 25$ ${ }^{\circ} \mathrm{C}$ ), giving a total of 36 simulated fire conditions in this study. Immediately upon the exposure time, three strips of $1 \mathrm{~cm} \times 1 \mathrm{~cm}$ were cut from randomly selected region of each burnt sample and placed in separate $10 \mathrm{~mL}$ glass vial (Supelco, Bellefonte, PA). Solvent extraction, adapted from ASTM E-1386, was performed by adding $5 \mathrm{~mL}$ hexane as organic solvent into the vials with samples and allowing it to stand for one hour [10]. All samples were then transferred and filtered into glass vials for GC analysis. 


\section{GC-FID analysis}

Analysis of gasoline was carried out using a 7890A gas chromatography-flame ionisation detector (GC-FID) equipped with G4513A series autosampler (Agilent Technologies, Santa Clara, CA). Chromatography was achieved using a HP-5 capillary column $(30 \mathrm{~m} \times 0.25 \mathrm{~mm} \times 0.25 \mu \mathrm{m}$ film thickness) purchased from Agilent Technologies. Purified nitrogen gas (99.9\%) was used as carrier gas with constant flow rate of $1.2 \mathrm{~mL} / \mathrm{min}$. Split mode (10:1) injection technique and the inlet temperature was set at $300{ }^{\circ} \mathrm{C}$. Oven was set at $50{ }^{\circ} \mathrm{C}$ as initial temperature for 2.5 mins, ramp at $15{ }^{\circ} \mathrm{C} / \mathrm{min}$ to $250{ }^{\circ} \mathrm{C}$, and held for 5.83 mins. Detector temperature was set at $300{ }^{\circ} \mathrm{C}$. Hydrogen flow, air flow and make up gas flow were set at 30,300 and $15 \mathrm{~mL} / \mathrm{min}$, respectively. Chemstation software (Rev. B.04.02, Agilent Technologies, Santa Clara, CA) was used for GC automation and data analysis. All extracted samples including positive and negative controls were analysed. Prior to analysis of burnt samples, neat gasoline was diluted with hexane $(1: 4, \mathrm{v} / \mathrm{v})$ and analysed to obtain its reference chromatogram. Note that blank was run between the samples to avoid carry-over. Gas chromatogram of each sample was compared and evaluated.

\section{Data analysis}

Using reference chromatogram of neat gasoline, the peak areas of 52 peaks with sufficient chromatographic features and intensity of the burnt samples were selected and integrated before being transferred to Microsoft Excel ${ }^{\circledR}$ Spread sheet (Microsoft office, Demond, WA). A bar chart was used to investigate the behaviour of gasoline peaks loss with time elapsed. For statistical analysis, two data pre-treatment procedures were considered in this study, namely by normalisation of each peak to the sum of peak areas in the respective regions that lied between 6 and 15 minutes $[11,12]$ and normalisation of each peak to the total sum of peak areas in a chromatogram [13]. Normalised peaks were then served as variables to Principle Component Analysis (PCA) for multivariate analysis using Minitab 16 software (Minitab Inc., State College, PA).

\section{GC-FID analysis}

\section{Results and Discussion}

Representative chromatogram profiles of neat gasoline, positive and negative controls were demonstrated in Figure 1. The chromatogram of positive control showed very similar profile as compared to the chromatogram profiles of neat gasoline, illustrated in respective Figures 1(a) and 1(b). Under our experimental condition, the carpet substrate showed no observable interference peaks additional to the profile of positive control, as demonstrated in Figure 1(c).

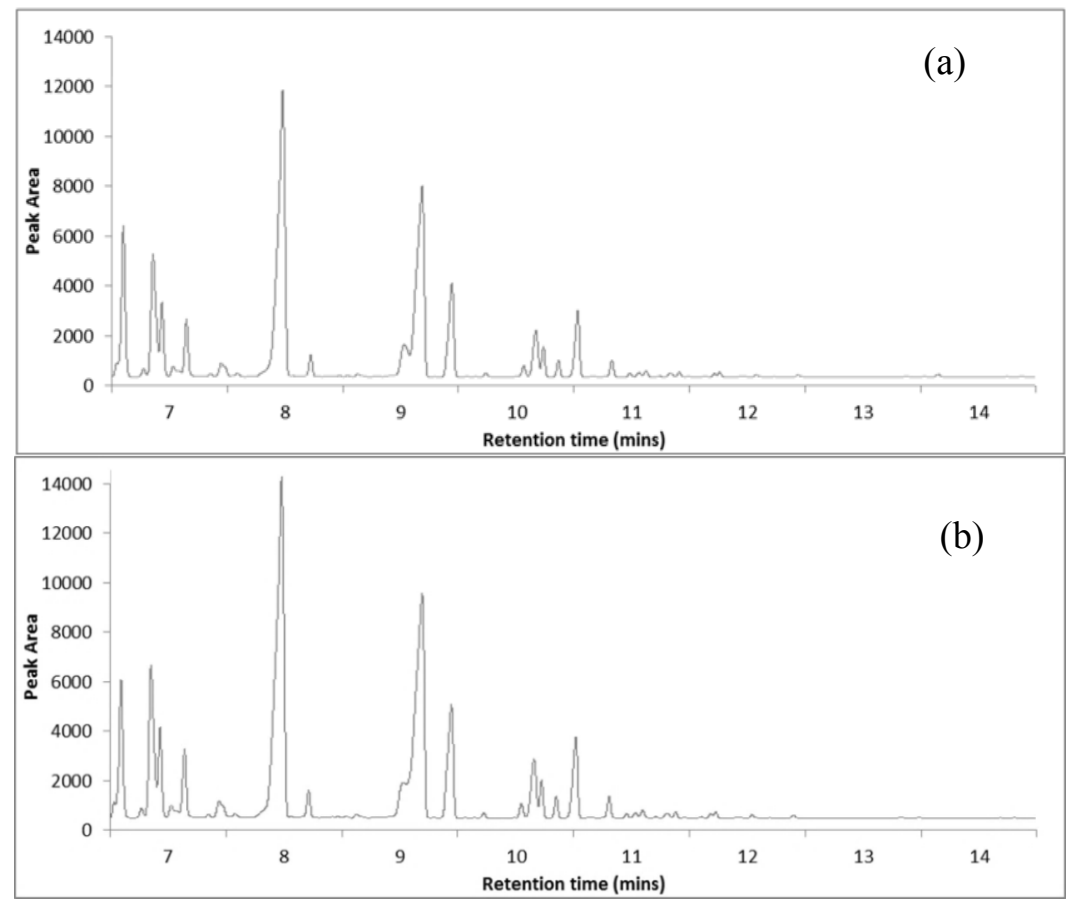




\section{Lim et al: FORENSIC GAS CHROMATOGRAPHY ANALYSIS OF TIME ELAPSED GASOLINE IN FIRE SCENE INVESTIGATION}

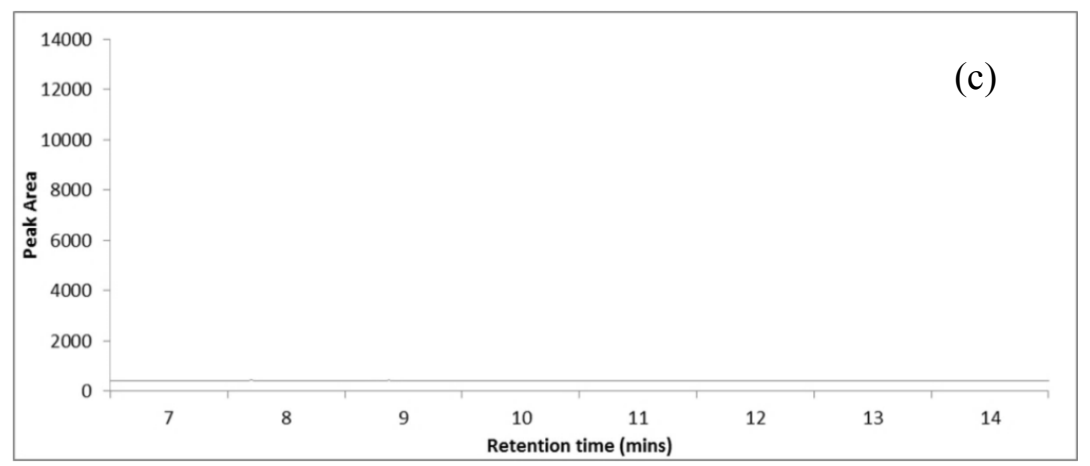

Figure 1. Representative chromatograms of (a) neat gasoline, (b) positive control and (c) negative control

The analytical parameters used in this study were adopted from ASTM E1618-06 method [14]. Due to complex features of gasoline, only well separated and symmetrical peaks were selected for data analysis. In our experiment, the same gasoline sample was used throughout the study to prevent any variation in chromatographic profile due to different gasoline samples. It is worth noting that no attempt was made to identify the identity of respective compounds of a particular retention time, since our aim is to make a relative comparison of the 52 selected peaks and their respective peak areas in relation to the varying time elapsed after a fire.

\section{Investigation of gasoline profile with time elapsed after a fire}

A chromatographic profile of gasoline contains mixture of alkanes, cycloalkanes, aromatic and condensed ring aromatic compounds $[14,15]$. These compounds carry different characteristics, which ranged from very low to relatively high volatilities. In our study, it was observed that lighter compounds in gasoline of lower retention times disappeared more rapidly than those heavier compounds. Lighter compounds, being more volatile, evaporated off faster from the burnt carpet samples and this observation was supported by review of Martín-Alberca et al. [16]. The tendency of losing more volatile or lighter weight compounds when ignitable liquids were subjected to evaporation alter their GC chromatographic features, making chromatogram comparison challenging.

Figure 2 shows a bar chart illustrating the percentage of selected peak remained in respective chromatogram based on time elapsed after a fire. At a glance, the decrease in the number of peaks that could be recovered from the burnt carpets was evident as compared to reference gasoline profile. An elapsed of nine hours after a fire dies out, almost $20 \%$ of peak loss was observed. Subsequently, approximately $50 \%$ loss in the number of selected peaks was seen after 24 hours. As a result, many peaks delineating the profile of gasoline were no longer detectable under the experimental condition. Results suggest that if a chromatographic profile showed only $20 \%$ of indicative peaks of gasoline, or upon exposure to room condition exposure for seven days (168 hours) upon suppression, it is difficult to confidently confirm the potential presence of gasoline to initiate arson. 


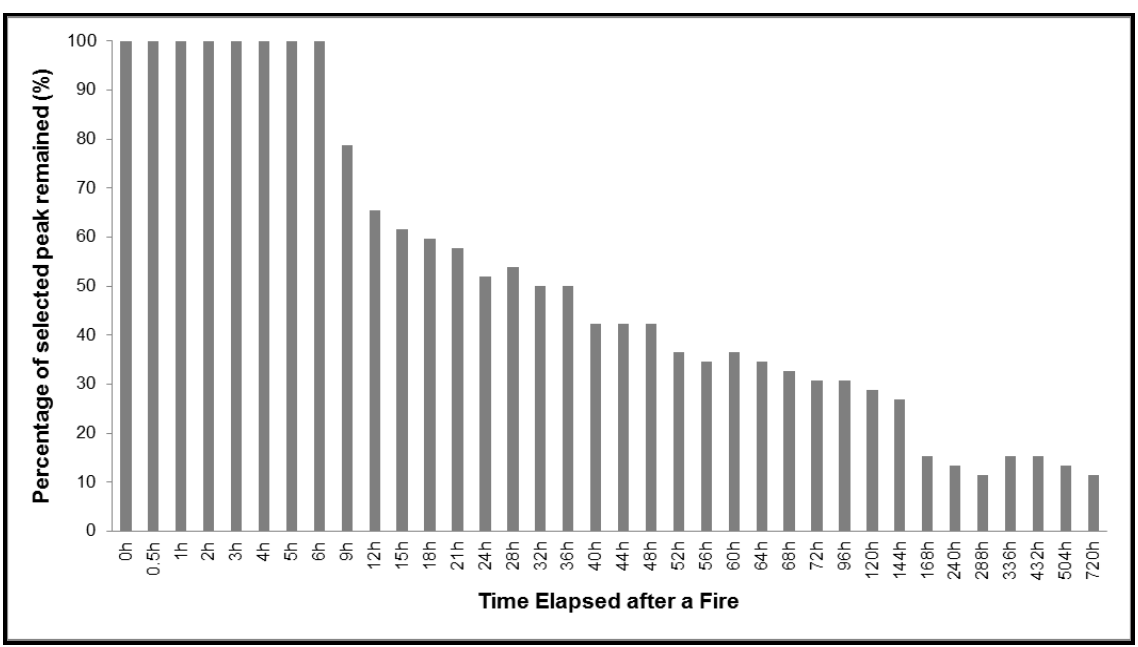

Figure 2. Bar chart illustrating the percentage of selected peak remained in respective chromatogram against the time elapsed after a fire

The amount of gasoline that could be recovered from burnt carpet samples at each time interval was further investigated by examining the abundance of respective compounds in nine separate regions. Figure 3 shows line graphs taken by slicing the normalised peaks into different regions of increasing retention times as represented by Regions A to I, depicting the relationship between the normalised peak areas of each region and the time elapsed after a fire. The Region A consisted of peaks which lie between retention times of 6 to 7 minutes, followed by different regions with consecutive retention time interval of one minute until Region I that spanned from the retention time of 14 to 15 minutes.

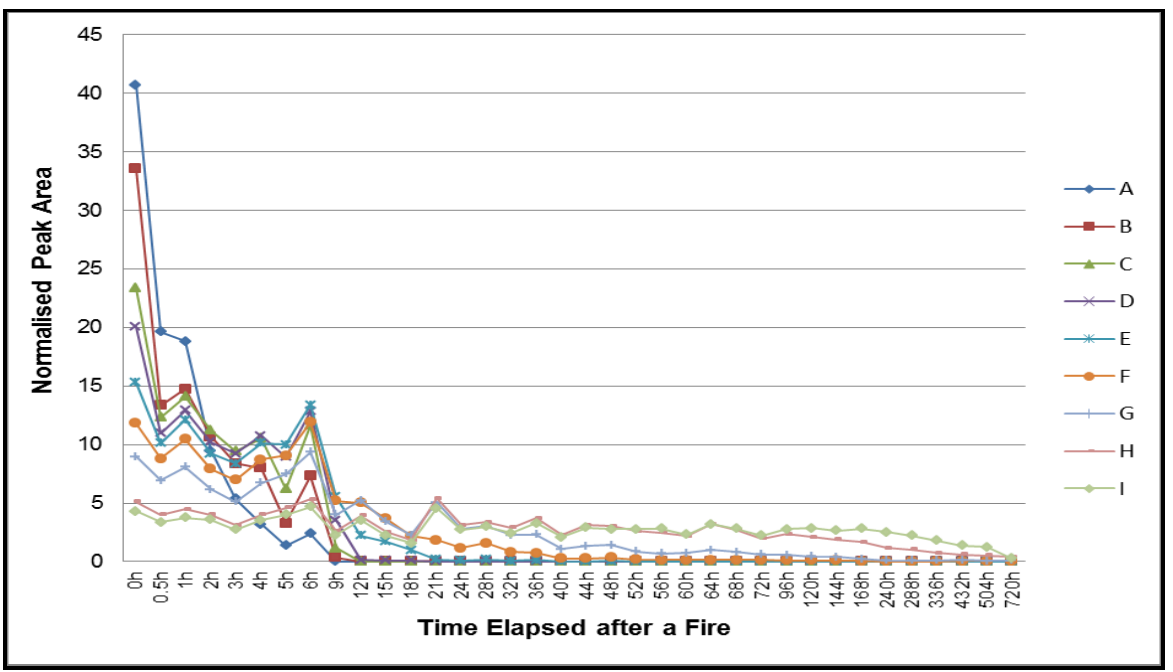

Figure 3. Line graphs of normalised peak area versus time elapsed after a fire

In general, all the line graphs in Figure 3 demonstrated downward trends where the peak areas decreased with time elapsed upon combustion. Generally, significant drop of peak areas during the first 30 minutes was evident and a continuous but non-linear decrease along with different time intervals up to one month of elapsed after a simulated fire. Similar observation was also reported by several previous studies evaluating the persistence of gasoline on 


\section{Lim et al: FORENSIC GAS CHROMATOGRAPHY ANALYSIS OF TIME ELAPSED GASOLINE IN FIRE SCENE INVESTIGATION}

various substrates, including Folkman et al. [17] on clothing, shoes, carpet and wood, Darrer et al. [18] on PVC gloves, Tan et al. [10] on various types of woods, as well as Dhabbah et al. [19] on carpet.

The lower retention times from Regions A to $\mathrm{E}$ were found to approach $\mathrm{X}$-axis faster than those indicating higher retention times from Regions $\mathrm{F}$ to I (Figure 3), which supports the finding where lighter compounds in gasoline evaporated more rapidly than relatively heavier compounds. Based on our experimental results, longer exposure time of gasoline to the surrounding was shown to potentially lead to greater difficulty in recovering gasoline residues from the burnt samples. However, in real case scenario, a fire could produce different outcomes on a gasoline profile due to uncontrollable factors, such as unequal distribution of gasoline throughout the carpet sample, burning rate, fire intensity, air flow and spread of fire which could directly or indirectly influenced the recovered amount of accelerant residues from fire debris [20].

\section{Principal component analysis}

The chromatographic profiles of burnt samples in relation to time elapsed were also subjected to multivariate analysis. Prior to PCA analysis, the experimental data was pre-treated by two different data normalisation to minimise the effect of highly abundance compounds. Figure 4 illustrates the score plot upon normalisation of selected peaks to the sum of peak areas in respective regions while Figure 5 exhibits the score plot subjected to normalisation of selected peaks to the total peak areas. Note that these score plots used the normalised abundance of selected peaks as 52 variables for PCA input data. PC and NC in the score plots indicate positive and negative controls, respectively.

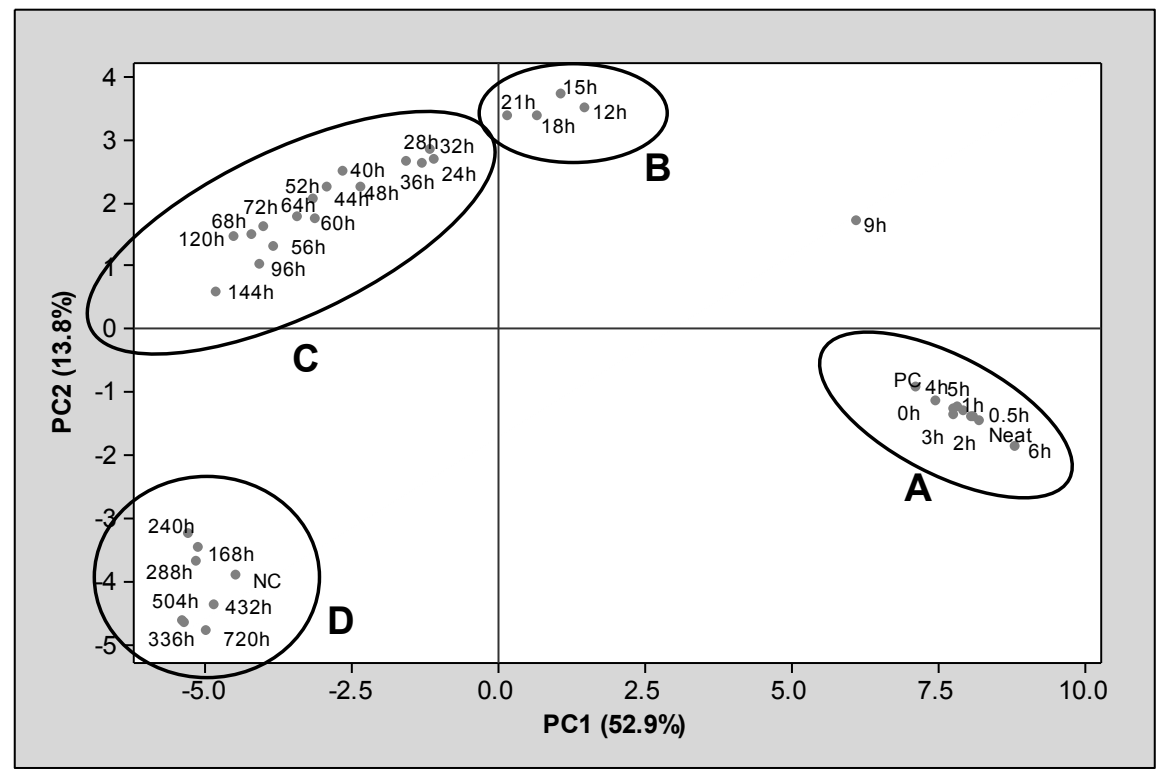

Figure 4. Score plot of burnt samples subjected to normalisation to the sum of peak areas in respective regions

Samples composing of very similar profiles tend to cluster together upon PCA. In both score plots, four different clusters were observed, namely clusters A, B, C and D, respectively. Visual comparison also showed that normalisation procedure based on different regions (Figure 4) has demonstrated better clustering of the samples into four distinctive clusters as shown in circles. As opposed to Figure 4, normalising the respective peak area to the total sum of peak areas in a chromatogram formed more loose clusters, particularly Cluster B and C, as shown in Figure 5. In our study, it was notable that different results could be obtained by the choice of data pre-treatment procedure prior to PCA. Both score plots have indicated the formation of four distinct clusters, but the members located in each cluster were found to vary suggesting the importance in utilising suitable data pre-treatment procedure to make data comparable. For our classification, normalisation according to different regions by 
comparison has shown with more distinctive clustering where the grouping of peak areas within desirable ranges has aided in trimming down the complexity and huge number of response [11,12].

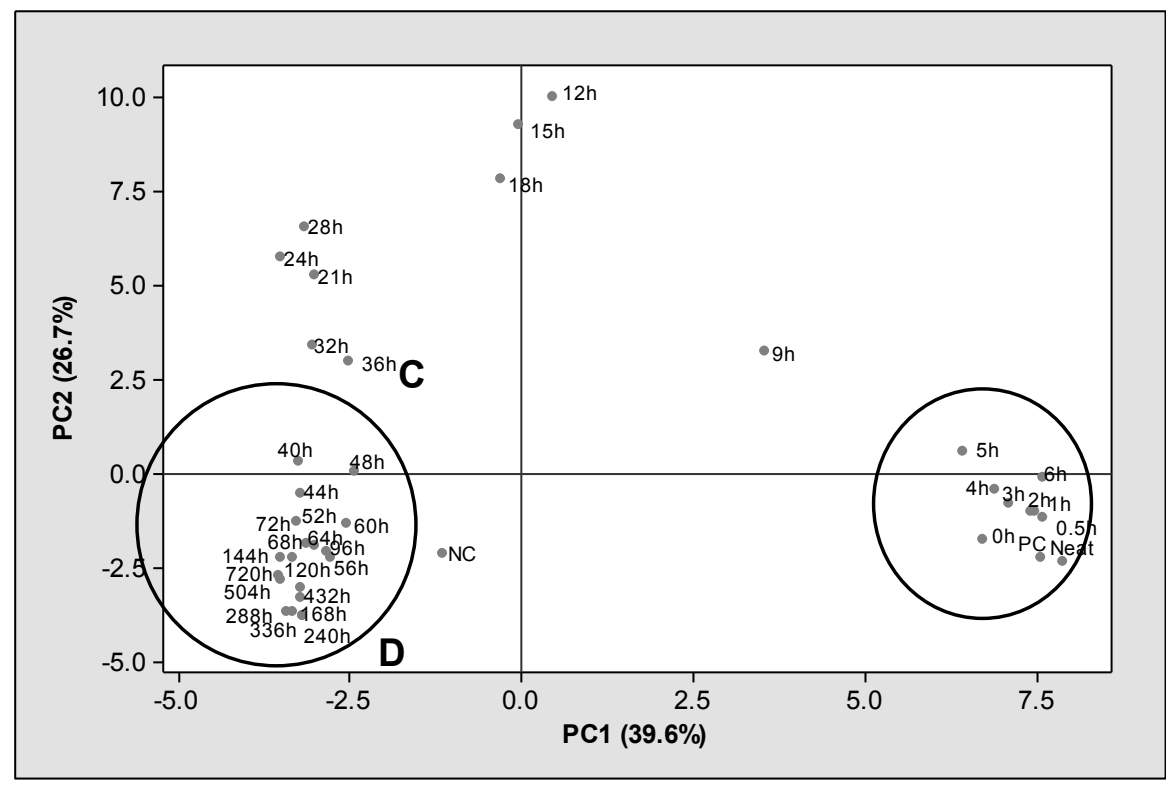

Figure 5. Score plot of burnt samples subjected to normalisation treatment to the total peak areas

Using peaks normalised based on regions as the variables for PCA, the result shows that the first two PCs accounted for $66.7 \%$ of the explained variance that distinguishing the burnt samples. PC1 (52.9\%) allowed the discrimination of burnt samples as a function of gasoline content. Samples in Cluster A showed positive score together with positive control, whereas those in Cluster D, including the negative control, showed negative score on PC1. It was also evident that data points were shifted from the right to left with exposure time elapsed. Examination on PC2 (13.8\%) shows that data points trajected downward to the left bottom of the score plot and assembled in Cluster D. After seven days of exposure upon combustion, the characteristic chromatographic profiles of a gasoline diminished making them be clustered closed to the negative control.

Generally, most samples in this study were clustered into four distinct clusters based on the two peak normalisation treatments, presuming that these samples could have different chromatographic profiles due to evaporative weathering process. For forensic intelligence, our findings suggested that the maximum recoverable time of gasoline residing within burnt carpet samples could remain recognisable up to nine hours under our experimental settings, retaining approximately $80 \%$ of the reference chromatographic peaks. However, the confirmation on the presence of gasoline from burnt samples could be difficult if the time elapsed was too long as seen in the samples exposed to seven days. In other words, the possibility to recover gasoline residues could be restricted, for instance in scenario where a re-sampling or re-analysing becomes necessary, it must be performed as soon as possible. This study suggests that a fire investigation and evidence collection should be started as soon as after fire suppression, preferably within nine hours and not more than seven days.

\section{Conclusion}

In contrast to our perception that accelerant residues could be protected in the substrate materials from environment insults, the study shows that immediate recovery of ignitable liquid residues upon fire suppression is important, as rapid sample loss occurred to have led to non-detection if the fire debris were left at the environment over an extended period. Therefore, in an event where a re-sampling or re-analysing is necessary, it should be performed as soon as possible. Collected samples should also be secured for further weathering if sample analysis could not be 


\section{Lim et al: FORENSIC GAS CHROMATOGRAPHY ANALYSIS OF TIME ELAPSED GASOLINE IN FIRE SCENE INVESTIGATION}

performed immediately. For future study, the factors such as the types of substrates and ignitable liquid used, duration of burning time, as well as the surrounding conditions during a fire, which could affect the recovery of ignitable liquid residues from fire debris should be investigated.

\section{Acknowledgement}

The authors thank Universiti Sains Malaysia for the financial support via the USM Short Term grant (304/PPSK/61313147). Special thanks to Associate Professor Lim Boon Huat and Associate Professor P.T. Jayaprakash for their editorial assistance.

\section{References}

1. De Haan, J. D. and Icove, D. J. (2011). Kirk's fire investigation. Pearson Higher Ed.

2. Fire and Rescue Department Malaysia. (2016). State/District Social Statistics Malaysia 2016. Department of Statistics Malaysia.

3. The Star. (2017). Fire department confirms tahfiz school fire deliberately ignited. http://www.thestar.com.my/ videos/2017/09/21/fire-department-confirms-tahfiz-school-fire-deliberately-ignited/.

[Access online 23 December 2017].

4. Redsicker, D. R. and O'Connor, J. J. (1996). Practical fire and arson investigation. CRC Press.

5. Thomson N. (2001). Technology \& engineering fire hazards in industry. Elsevier, Salford.

6. Stauffer, E., Dolan, J. A. and Newman, R. (2007). Fire debris analysis. Academic Press.

7. Baechler S., Comment S., and Delemont O. (2010). Extraction and concentration of vapors from fire debris for forensic purposes: evaluation of the use of radiello passive air sampler. Talanta, 82(4):1247 - 1253.

8. Cacho, J. I., Campillo, N., Aliste, M., Vinas, P. and Hernandez-Cordoba, M. (2014). Headspace sorptive extraction for the detection of combustion accelerants in fire debris. Forensic Science International, 238: $26-32$.

9. Almirall, J. R. and Furton, K. G. (2016). Analysis and interpretation of fire scene evidence. CRC Press.

10. ASTM. (2015). E1386-15 Standard practice for separation of ignitable liquid residues from fire debris samples by solvent extraction. ASTM International, West Conshohocken.

11. Tan, B., Hardy, J. K. and Snavely, R. E. (2000). Accelerant classification by gas chromatography/mass spectrometry and multivariate pattern recognition. Analytica Chimica Acta, 422: 37 - 46.

12. Ribeiro, J., Teófilo, R., Augusto, F. and Ferreira, M. (2010). Simultaneous optimization of the microextraction of coffee volatiles using response surface methodology and principal component analysis. Chemometrics and Intelligent Laboratory Systems, 102: 45 - 52.

13. Samri, M. A. S. and Chang K. H. (2016). Gas chromatography based forensic analysis of gasoline from burnt carpets retrieved using different fire extinguishing methods. Malaysian Journal of Forensic Sciences, 7(1): $39-44$.

14. ASTM. (2014). E1618-06 standard test methods for ignitable liquid residues in extracts from fire debris samples by gas chromatography-mass spectrometry. ASTM International, West Conshohocken.

15. Prather, K. R., McGuffin, V. L. and Waddell Smith, R. (2012). Effect of evaporation and matrix interferences on the association of simulated ignitable liquid residues to the corresponding liquid standard. Forensic Science International, 222(1-3): 242 - 251.

16. Martín-Alberca, C., Ortega-Ojeda, F. E. and Garcia-Ruiz, C. (2016). Analytical tools for the analysis of fire debris: A review: 2008-2015. Analytica Chimica Acta, 928: 1 - 19.

17. Folkman, T., Kuehl, A., Groves, R. and Beveridge, A. (1990). Evaporation rate of gasoline from shoes, clothing, wood and carpet materials and kerosene from shoes and clothing. Canadian Society of Forensic Science Journal, 23: 49 - 59.

18. Darrer, M., Jacquemet-Papilloud, J. and Delémont, O. (2008). Gasoline on hands: Preliminary study on collection and persistence. Forensic Science International, 175: 171 - 178.

19. Dhabbah, A. M., Al-Jaber, S. S., Al-Ghamdi, A. H. and Aqel, A. (2014). Determination of gasoline residues on carpets by SPME-GC-MS technique. Arabian Journal for Science and Engineering, 39: 6749 - 6756.

20. Mach, M. (1977). Gas chromatography-mass spectrometry of simulated arson residue using gasoline as an accelerant. Journal of Forensic Sciences, 22: 348 - 357. 